\title{
JUDICIAL INTERPRETATIONS OF DEMOCRACY IN HUMAN RIGHTS TREATIES
}

\author{
Jure Vidmar
}

\begin{abstract}
Human rights treaties contain provisions for the so-called democratic rights. These provisions are textually almost identical in various regional and universal human rights treaties, yet courts and other judicial bodies have constructed diverse understandings of democracy through interpretation. The main questions that arise are whether human rights treaties require a multiparty political setting and how they accommodate limitations on the will of the people. This article analyses developments in the context of the ICCPR and the three regional systems. It demonstrates that human rights courts have clearly established a requirement for multiparty elections and have even attempted a more robust, substantive definition of democracy. However, a new problem has arisen in recent case law. The electoral process has become dominated by political parties and electoral systems have often proven to be unable to accommodate independent candidates. The result is that candidates wishing to run at elections may be forced to associate with others. The contemporary interpretation of human rights treaties does not necessarily provide for suitable avenues to take part in elections outside of the framework of party politics. If it was once questionable whether human rights treaties guarantee the right to associate in political parties, it now seems that parties have become too central in the exercise of the so-called democratic rights.
\end{abstract}

\section{Keywords}

human rights, democracy, political participation, elections, interpretation

\section{Introduction}

Human rights treaties, both universal and regional, contain provisions for the so-called 'democratic rights': the right to political participation, the freedom of association, and the freedom of expression. They also contain the phrase

\footnotetext{
"Leverhulme Early Career Fellow, Faculty of Law, University of Oxford; Research Fellow, St John's College, Oxford; Extraordinary Lecturer, Centre for Human Rights, University of Pretoria; Visiting Fellow, Harvard Law School. The author would like to thank Prof Frans Viljoen for most helpful suggestions at an earlier stage of drafting, and the anonymous reviewers of the CJICL for constructive criticism and thought-provoking comments. Any remaining errors are the author's own.
}

Copyright $\odot$ the Author(s).

This work is licensed under a Creative Commons Attribution-NonCommercial-NoDerivs 3.0 License. 
'necessary in a democratic society' as a limitation clause to certain human rights. ${ }^{1}$ Although worded slightly differently, the text of these provisions is virtually identical in all human rights treaties. However, different interpretations have developed through judicial practice. A particularly difficult question is whether, and if so which, human rights treaties require a democratic political order with elections in a multiparty setting.

The interpretation that international human rights treaties have the political system of multiparty democracy in mind is not universally accepted. This is reaffirmed by the fact that the International Covenant on Civil and Political Rights (ICCPR) was drafted in the Cold War era. Since the ICCPR did not mention multiparty competition, it was arguable that the Communist notion of a single-party 'people's democracy' could also be compatible with the Convention rights. $^{2}$ Subsequently, some legal scholars have argued that, with the end of the Cold War, the interpretation of the ICCPR had changed and that democracy itself had become an international human right. ${ }^{3}$ Others challenged this position, inter alia, by pointing out that democracy remains a rather vague term. Indeed, political theorists disagree as to whether democracy can be defined in a narrow procedural manner, in terms of an institutional arrangement for free and fair elections, or whether democracy requires a more substantive definition. ${ }^{4}$

This article is not concerned with the various definitions of democracy offered in political theory; it rather looks for the understanding of democracy

1 The clause appears in the Universal Declaration of Human Rights, GA Res 217A (III), 10 December 1948; International Covenant on Economic, Social and Cultural Rights, 16 December 1966, 993 UNTS 3; International Covenant on Civil and Political Rights, 16 December 1966, 999 UNTS 171; Convention on the Rights of the Child, 20 November 1989, 1577 UNTS 3; International Convention on the Protection of the Rights of All Migrant Workers and Members of Their Families, 18 December 1990, 2220 UNTS 3; American Convention on Human Rights, 21 November 1969, 1144 UNTS 123; and the European Convention for the Protection of Human Rights and Fundamental Freedoms, 4 November 1950, 213 UNTS 221.

2 B Roth, Governmental Illegitimacy in International Law (1999) 332.

3 Ibid. See also T Franck, 'The Emerging Right to Democratic Governance' (1992) 86 AJIL 46; T Franck, 'Democracy as a Human Right', in L Henkin and J Hargrove (eds), Human Rights: An Agenda for the Next Century (1994); T Franck, 'Legitimacy and the Democratic Entitlement' in G Fox and B Roth (eds), Democratic Governance and International Law (2001); F Teson, "The Kantian Theory of International Law' (1992) 92 Columbia LR 53; A Slaughter, 'International Law in a World of Liberal States' (1995) 6 EJIL 503; and A Slaughter, 'The Real New World Order' (1997) 76 Foreign Affairs 183.

${ }^{4}$ See S Marks, The Riddle of All Constitutions (2000); Roth, above n 2; J Alvarez, 'Do Liberal States Behave Better? A Critique of Slaughter's Liberal Theory' (2001) 12 EJIL 183; J d'Aspremont, 'The Rise and Fall of Democratic Governance in International Law: A Reply to Susan Marks' (2011) 22 EJIL 549. 
in judicial practice. Its first task is to analyse how judicial bodies interpret the relationship between the so-called 'democratic rights' and political parties in human rights treaties. There are two aspects to this relationship. First, it is questionable whether judicial bodies interpret these treaty obligations as requiring multiparty electoral procedures. Second, there may be some indication in case law that the right to political participation has, in fact, become dominated by the requirement for a multiparty political system. Does the contemporary interpretation of human rights treaties provide for suitable avenues to take part in elections outside of the party politics framework, or has party politics become a presupposed institutional arrangement in international human rights law?

Furthermore, the article looks for judicial interpretations of democracy that reach beyond electoral procedures and refer to its substantive tenets. In the context of the 'necessary in a democratic society' limitation clause, a judicial practice has developed of limiting 'democratic rights' in order to protect democracy. This practice proves that democracy in judicial practice is not understood as majority rule crystallised through the electoral process. How do courts identify and interpret the non-democratic nature of a certain political force? How do they interpret legal obligations generated by the principle of democracy? Can such interpretations be universalised, or are they context and society specific, perhaps limited to a particular regional human rights arrangement?

The article analyses developments in the context of the ICCPR and the three regional systems: the European Convention for the Protection of Human Rights and Fundamental Freedoms (ECHR), the American Convention on Human Rights $(A C H R)$, and the African Charter on Human and Peoples' Rights (ACHPR). It first determines the relationship between 'democratic rights' and political parties and then considers how a more substantive understanding of democracy has been developed through the interpretation of 'necessary in a democratic society'. It demonstrates that regional human rights courts have clearly established a requirement for multiparty elections on the basis of human rights treaties. Indeed, political parties are so important for the exercise of certain 'democratic rights' that courts have even limited the possibility for individuals to participate outside of the established framework of party politics. At the same time, courts have taken a more robust approach and decided that democracy does not simply comprise majority rule. 


\section{Interpreting the relationship between 'democratic rights' and political parties}

The right most commonly associated with democracy is the right to political participation as it relates to elections, the most tangible element of a democratic process. ${ }^{5}$ However, no international human rights treaty, universal or regional, textually specifies that elections need to take place in a multiparty setting. A definition of democracy then falls on judicial bodies when interpreting the obligations stemming from human rights treaties. In this section, it will be demonstrated that no authoritative (judicial) interpretation exists for holding that the right to political participation requires a particular multiparty setting in the ICCPR context. This is different in regional human rights arrangements, where political parties are deemed so central for the exercise of 'democratic rights' that individuals have been precluded from participation in the political process without their support. However, such practice may lead to the infringement of certain rights.

\subsection{The requirement of multiparty elections in human rights treaties}

At the level of universal human rights instruments, the right to political participation is contained in Article 21 of the Universal Declaration of Human Rights $(U D H R)$ and Article 25 of the ICCPR. Neither instrument specifically requires elections to take place in a multiparty setting. ${ }^{6}$ A 'multiparty interpretation' was also omitted in the United Nations Human Rights Committee (HRC) Comment on Article 25. ${ }^{7}$ In the Nicaragua case, the International Court of Justice (ICJ) interpreted the 'democratic rights' textually and concluded: '[T]he Court cannot find an instrument with legal force, whether unilateral or synallagmatic, whereby Nicaragua has committed itself in respect of the principle or methods of holding elections. ${ }^{8}$ Notably, Nicaragua was a party to the ICCPR and bound by the pro-

\footnotetext{
5 See T Carothers, 'Empirical Perspectives on the Emerging Norm of Democracy in International Law' (1992) ASIL Proc 261, 264.

6 The amendment to Article 21 of the UDHR, which would call for multiparty elections, was withdrawn upon a protest by the Soviet government. See Roth, above n 2, 326-7.

7 HRC, General Comment 25, para 1.

8 Military and Paramilitary Activities in and Against Nicaragua (Nicaragua $v$ United States), ICJ Reports 1986 p 14, 132 (Nicaragua).
} 
visions of the right to political participation, the freedom of assembly, and the freedom of speech.

After the end of the Cold War, a number of references to holding elections in a multiparty setting were made in the documents adopted in the UN framework. ${ }^{9}$ However, these are all 'soft law' documents, supported by too few states to indicate general practice and/or opinio juris. Conversely, the General Assembly adopted a set of resolutions on supporting, promoting, consolidating and enhancing democracy. ${ }^{10}$ These resolutions not only fail to specify that elections need to take place in a multiparty setting, but also affirm that the choice of political system is a domestic matter for each state. ${ }^{11}$ The language of these resolutions remains within the textual parameters of the ICCPR. They specifically state that 'while democracies share common features, there is no single model of democracy [...] it does not belong to any country or region.12 Democracy is also mentioned in some other documents adopted in the UN framework, such as the Vienna Declaration and Programme of Action ${ }^{13}$, and the Millennium Declaration. ${ }^{14}$ These references remain rather general and do not mention that the right to political participation could only be consummated in a multiparty setting. These widely supported resolutions may be seen as indicators of the universal understanding of democracy under the ICCPR and customary international law.

In essence, subsequent practice of states and UN organs affirms the ICJ's 1986 Nicaragua pronouncement: international (human rights) law does not require a specific political system in general or multiparty elections in particular. This is different in the framework of regional human rights treaties where the 'democratic rights' are textually reminiscent of those found in the ICCPR, but

\footnotetext{
9 See Commission on Human Rights Resolution 1999/57, 27 April 1999; Commission on Human Rights Resolution 2000/47, 25 April 2000; Commission on Human Rights Resolution 2002/46, 23 April 2002.

${ }^{10}$ GA Res 45/150, 18 December 1990. The Resolution was adopted with a vote of 129 in favour and eight against, with nine abstentions: GA Res 45/151, 18 December 1990. The Resolution was adopted with a vote of 111 in favour and 29 against, with 11 abstentions: GA Res 50/133, 20 December 1995; GA Res 51/31, 13 December 1996; GA Res 52/18, 21 November 1997; GA Res 53/31, 23 November 1998; GA Res 54/36, 29 November 1999; GA Res 55/43, 27 November 2000; GA Res 58/13, 17 November 2003; GA Res 58/281, 9 February 2004; GA Res 60/253, 2 May 2006; and GA Res 61/226, 22 December 2006.

${ }^{11}$ GA Res 60/253, preamble, para 11; GA Res 61/226, preamble, para 8; and GA Res 62/7, preamble, para 8.

12 GA Res 60/1, 24 October 2005, para 135.

${ }^{13}$ World Conference on Human Rights, Vienna Declaration and Programme of Action, UN Doc A/CONF.157/23, 12 July 1993.

${ }^{14}$ GA Res 55/2, 8 September 2000, paras 24 and 25.
} 
regional bodies interpret them with a specific idea of democracy in mind.

In the framework of the ECHR, the right to vote did not originally appear in the Convention itself but was subsequently included in Article 3 of Protocol $1 .^{15}$ The question of whether elections need to be held in a multiparty setting was most prominently addressed in the context of other 'democratic rights' contained in the ECHR. In a number of cases concerning the freedom of assembly, the European Court did not initially venture into the question of whether the right covers political parties and thus guarantees multiparty elections. But in Young, James and Webster $v$ United Kingdom, the Court established a close link between Article 9 (freedom of thought, conscience and religion), Article 10 (freedom of expression) and Article 11 (freedom of assembly and association), arguing that the realisation of one right is not possible without the realisation of another. ${ }^{16}$

While Article 11 of the ECHR specifically mentions trade unions but not political parties, in a series of Turkish cases, the Court departed from strict textual interpretation when it had to decide whether prohibiting and dissolving a certain political party could fall within the 'necessary in a democratic society' limitation clause. In United Communist Party of Turkey v Turkey, the Court reasoned:

It is [...] not possible to conclude, as the Government [of Turkey] did, that by referring to trade unions [...] those who drafted the Convention intended to exclude political parties from the scope of Article $11 .^{17}$

The Court went on to invoke elections in a multiparty setting:

$[\mathrm{P}]$ olitical parties are a form of association essential to the proper functioning of democracy. In view of the importance of democracy in the Convention [...] there can be no doubt that political parties come within the scope of Article 11 [...] [P]olitical parties make an irreplaceable contribution to political debate, which is at the very core of the concept of a democratic society. ${ }^{18}$

Although the provision guaranteeing the freedom of assembly in the ECHR is textually very similar to that in the ICCPR, the European Court's interpretation

\footnotetext{
15 Protocol 1 to the European Convention for the Protection of Human Rights and Fundamental Freedoms, 20 March 1952, ETS 9, Art 3.

${ }^{16}$ Young, James and Webster v United Kingdom (1982) 4 EHRR 38, para 57.

17 United Communist Party of Turkey and Others v Turkey (1998) 26 EHRR 121, para 24.

18 Ibid, paras 25 and 44.
} 
has established a close-knit relationship between human rights and multiparty democracy in the European context. While the ICCPR and customary international law do not bind states to hold elections in a multiparty setting, this cannot be said for the ECHR. In the African and Inter-American regional systems, no case has directly addressed the issue of whether the underlying human rights treaties require multiparty elections. The ACHPR and ACHR guarantee the right to political participation in Article 13 and Article 23 respectively. Similarly to comparable provisions in the ICCPR and ECHR, they omit a reference to multiparty elections and leave specific modalities of the right to interpretation by the African Court and the Inter-American Court. However, these courts had to address another aspect of the relationship between political parties and the 'democratic rights': whether candidates can be forced to associate with political parties if they wish to run at elections.

\subsection{Political parties as an institutional requirement for political participation}

In Tanganyika Law Society v Tanzania, the African Court had to consider the Tanzanian constitutional requirement that anyone wishing to stand for an election be a member of a political party. ${ }^{19}$ The Court decided that this requirement infringed Article 13 of the ACHPR, ${ }^{20}$ which provides that '[e]very citizen shall have the right to participate freely in the government of his country, either directly or through freely chosen representatives in accordance with the provisions of the law. ${ }^{21}$ The constitutional provision at issue only discriminated against independent candidates and not against any political party. The applicant in that case was not intending to run with his own party or list but as an independent individual. ${ }^{22}$ The decision, therefore, does not directly confirm that elections in the framework of the ACHPR would need to be multiparty.

A broader interpretation of the ACHPR could follow from the interdependence of Article 13 with other 'democratic rights', in particular the freedom of association (Article 11). ${ }^{23}$ When considering this right, the African Court remained

\footnotetext{
${ }^{19}$ Tanganyika Law Society and Legal and Human Rights Centre $v$ The United Republic of Tanzania, Application No 009/2011, Judgment of 14 June 2013 (The African Court of Human and Peoples' Rights).

${ }^{20}$ Ibid, para 111.

${ }^{21}$ ACHPR, Art 13(1).

${ }^{22}$ Tanganyika Law Society, above n 19, para 93.

${ }^{23}$ ACHPR, Article 11.
} 
confined to the facts of the case and did not interpret Article 11 as analogous to the European Court's interpretation of the freedom of assembly. ${ }^{24}$ Rather, the African Court found a violation of the freedom of association based on their interpretation of the Tanzanian constitutional provision, 'an individual is forced to associate with others. ${ }^{25}$

In contrast with the Strasbourg jurisprudence discussed above, the African Court had to define the relationship between political parties and 'democratic rights' from the other direction: whether individuals can be forced to join a political party in order to run at an election. The answer was negative, as one cannot be forced to associate with others. In effect, through its interpretation of the freedom of association, the African Court has now established that the democratic electoral process is not only reserved for political parties but that individuals may also run. While acknowledging the importance of political parties in a democracy, the Court upheld the view that democratic elections can also accommodate individuals who choose to participate outside of the institutionalised party framework.

A somewhat similar problem to Tanganyika Law Society was brought to the HRC in AP v Russia. ${ }^{26}$ In 2007, the Russian Electoral Commission was unable to register a citizen wishing to run in the parliamentary elections who was not a member of any political party. The Electoral Commission told the citizen that he could still 'apply to any regional branch of any political party for his inclusion in the federal list of candidates to be nominated by that political party. ${ }^{27}$ In other words, the Electoral Commission referred him to political parties in order to participate in the electoral process. Importantly, he would not need to become a member of any party, but would 'only' need to join a party list as an independent candidate. Conversely, in Tanzania, the option to run as a non-party member with party support was not available. ${ }^{28}$

On this basis, judicial bodies are trying to draw a fine line between being forced to join a political party and being forced 'only' to be included on a party list. $^{29}$ The former would be unacceptable, while the latter is seen as a reasonable alternative which enables individuals to run without having to join a party. The

\footnotetext{
${ }^{24} \mathrm{Cf}$ above $\mathrm{n} 17$.

${ }^{25}$ Tanganyika Law Society, above n 19, para 113.

${ }^{26}$ HRC, Communication No 1857/2008, UN Doc CCPR/C/107/D/1857/2008, 10 May 2013 (AP v Russia).

${ }^{27}$ Ibid, para 2.2 .

${ }^{28}$ Tanganyika Law Society, above n 19, para 107.3.

${ }^{29}$ Ibid.
} 
line is artificial because joining a party list, even as a non-member, implies acceptance of that party's programme and ideology. AP v Russia illustrates this problem, as the complainant was not interested in running as a non-member on any party list and simply did not want to be connected to any political party in any way. On this basis he alleged several violations of the ICCPR, including Article $25 .^{30}$

The HRC concluded that the application was inadmissible. With regard to Article 25, it noted that the complainant had a domestic remedy available if a political party refused to put him on its list as an independent candidate (i.e. non-member of that particular party). ${ }^{31}$ However, the complainant was not in the position to use this remedy, as he did not even try to be included on a party list. In the end, the HRC added that the complaint contained 'no information as to why the author could not create his own political party together with individuals sharing similar political opinions and stand for elections through it. ${ }^{32}$ The HRC was clearly eager to declare the complaint inadmissible but, in so doing, it re-categorised the original problem. A domestic remedy may well have existed had the complainant tried to register for a party list and was refused the right to do so. But this is precisely what the complainant did not want to do-he wanted to run without having anything to do with political parties. In such circumstances, he had no domestic remedy to challenge the Russian law which could not accommodate candidates without a party backing.

In Tanganyika Law Society, the approach was quite different and the African Court did not tell the applicant either to pick an existing party or create his own. Rather, it found the requirement to participate in the electoral process exclusively through political parties incompatible with the ACHPR. Nevertheless, it must be noted that the 'middle option' of running on a party list as a non-member was unavailable in Tanzania, where the electoral system is based on single-member constituencies, with a number of seats reserved for female candidates. ${ }^{33}$ The latter quota is distributed according to proportionate voting, while the basic 'first-past-the-post' system can accommodate independent candidates and does not require party lists. In contrast, the 2007 elections in Russia used a pure proportionate system, the central feature of which is party lists that cannot

\footnotetext{
${ }^{30}$ AP v Russia, above n 26, para 3.1.

${ }^{31}$ Ibid, para 10.6.

${ }^{32}$ Ibid.

${ }^{33}$ See 'Tanzania: Electoral System', Electoral Institute for Sustainable Democracy in Africa, $<$ http://eisa.org.za/WEP/tan4.htm> [accessed 1 March 2014].
} 
accommodate individual candidates who are not on a list. ${ }^{34}$ Had the complaint in AP v Russia proceeded to be considered on the merits, the HRC would have been asked to address the problem of political participation being monopolised by political parties. In particular, it would have considered why Article 25, which does not mention political parties at all, allows for complete exclusion of the ability to run at elections without being associated with a party, at least as a non-member supported by one of the parties.

The question omitted by the HRC has been addressed by the Inter-American Court of Human Rights in Castañeda Gutman v Mexico. ${ }^{35}$ In that case, the complainant intended to run as an independent candidate at presidential, not parliamentary, elections, but would nevertheless only be entitled to do so if he were backed by a political party, albeit as a non-member. The Inter-American Court ruled that the requirement to seek party support was not an infringement of Article 23 of the ACHR. In reaching this conclusion, the Court noted that:

In the sphere of political rights the guarantee obligation is especially relevant and is implemented, among other mechanisms, by the establishment of the organizational and institutional aspects of the electoral processes, and by the enactment of norms and the adoption of different types of measures to implement the rights and opportunities recognized in Article 23 of the Convention. ${ }^{36}$

The Court further recalled that the ACHR, "like other international human rights treaties, does not establish the obligation to implement a specific electoral system. Nor does it establish a specific mandate on the mechanism that the States must establish to regulate the exercise of the right to be elected in general elections, ${ }^{37}$

Similarly, in Mathieu-Mohin and Clerfayt v Belgium, the European Court held:

[T] he Contracting States have a wide margin of appreciation, given that their legislation on the matter (the electoral system) varies from place to place and from time to time [...] It does not follow [...] that all votes must necessarily have equal weight as regards the outcome

\footnotetext{
34 'How the Duma Electoral System Works', Centre for the Study of Public Policy, University of Strathclyde, <http://www.russiavotes.org/duma/duma_electoral_system.php > [accessed 1 March 2014].

${ }^{35}$ Castañeda-Gutman v Mexico, Judgment of 6 August 2008 (Inter-American Court of Human Rights).

${ }^{36}$ Ibid, para 159.

${ }^{37}$ Ibid, para 197.
} 
of the election or that all candidates must have equal chances of victory. Thus no electoral system can eliminate 'wasted votes' [...] any electoral system must be assessed in the light of the political evolution of the country concerned; features that would be unacceptable in the context of one system may accordingly be justified in the context of another, at least so long as the chosen system provides for conditions which will ensure the 'free expression of the opinion of the people in the choice of the legislature. ${ }^{38}$

The Court's interpretation of the ECHR does not specify the exact modalities or precise technical arrangements to be implemented at national elections. Rather, there is a margin of appreciation, as there exists no ideal electoral system which would be suitable for all states, regardless of historical, political, geographical, social and other differences.

The pronouncement that human rights treaties do not require a particular electoral system is certainly doctrinally sound and its basic premise is not contestable. However, it is debatable whether, in the context of presidential elections such as in Castañeda Gutman, the requirement to seek party support is really an institutional aspect of the electoral process. The problem is that such elections do not require party lists. It is arguable that the Inter-American Court's reasoning would be plausible in a case such as AP v Russia, that is, in the circumstances of parliamentary elections in a proportionate electoral system. Party lists are a central feature of such an electoral system and can be seen as an 'institutional aspect of the electoral process. ${ }^{39}$ But they play no institutional role in presidential and 'first-past-the-post' parliamentary elections, where votes are given to specific individuals. The Inter-American Court did not acknowledge this difference and made passive exercise of the right to vote conditional on involvement in party politics, albeit without a requirement to formally join a political party.

The relationship between political parties and 'democratic rights' has long been dominated by the question of whether human rights treaties require multiparty elections. Recent case law has presented the problem from the other direction: can national legislation require that the right to stand for an election only be consummated through party politics, not necessarily by membership but at least by inclusion on party lists? Relevant cases before different judicial bodies are not entirely comparable because different factual circumstances determine

\footnotetext{
${ }^{38}$ Mathieu-Mohin and Clerfayt v Belgium (1987) 10 EHRR 1, para 54.

${ }^{39}$ See above $\mathrm{n} 36$.
} 
each case. Nevertheless, it seems to be increasingly accepted that the right to political participation needs to take place in a multiparty setting and states need to make institutional arrangements necessary for such a political system. Sometimes these institutional arrangements will discriminate against candidates who want to run without being associated with any political party. In this context, courts have established an artificial line between the requirement to join a political party and the requirement 'only' to be supported by a political party in order to run at an election. In both circumstances, an individual is, however, forced to associate with a political party, even if not always formally as a member.

While the Inter-American Court was right in claiming that implementation of specific electoral systems falls to be determined by states, there is little reason to make candidates seek party support in those electoral systems which do not operate on the proportionate system of party lists. In other words, the requirement to seek party support may be justifiable in some electoral systems but not others. In AP v Russia, the HRC missed an opportunity to set such a precedent at the ICCPR level. It remains to be seen whether regional human rights courts will further develop the distinction between 'being a party member' and 'being merely supported by a party', or whether they will start scrutinising electoral systems and establish that some of them can institutionally accommodate candidates even if they run without party support.

\section{Interpreting limitations on democratic rights}

Thus far, it has been established that universal and regional human rights treaties contain virtually identical textual provisions guaranteeing 'democratic rights', but that their scope crucially depends on judicial interpretation. Regional human rights case law has given much prominence to political parties, but the HRC remains evasive and has yet to clarify the precise relationship between political parties and 'democratic rights'. This section will analyse the judicial interpretations of the limitation clauses in human rights treaties, which allow human rights to be limited in the interest of 'a democratic society'.

\subsection{The interpretation of the limitation clauses}

A number of international human rights instruments contain the phrase 'democratic society' as a limitation clause. This reference initially appeared in Article 
29(2) of the UDHR; ${ }^{40}$ the human rights provisions contained in it may be limited if the interests of a 'democratic society' so requires. As a limitation clause attached to specific human rights provisions, the phrase also found its place in a number of international human rights treaties. The International Covenant on Economic, Social and Cultural Rights (ICESCR) comprehends a general limitation clause in Article 4:

The States Parties to the present Covenant recognize that, in the enjoyment of those rights provided by the State in conformity with the present Covenant, the State may subject such rights only to such limitations as are determined by law only in so far as this may be compatible with the nature of these rights and solely for the purpose of promoting the general welfare in a democratic society. ${ }^{41}$

The ICESCR also refers to a 'democratic society' as part of the limitation clause in the context of the right to form trade unions. ${ }^{42}$ The ICCPR attaches the interests of a 'democratic society' as one of the limitation clauses to the right to a fair trial, ${ }^{43}$ freedom of assembly, ${ }^{44}$ and freedom of association. ${ }^{45}$ The Convention on the Rights of the Child $(C R C)$ invokes the interests of a 'democratic society' as a limitation clause to the rights of a child to freedom of association and assembly. ${ }^{46}$ The International Convention on the Protection of the Rights of All Migrant Workers and Members of Their Families (ICPRMW) attaches the interests of a 'democratic society' within the limitation clause to the right of migrant workers to take part in the trade unions, ${ }^{47}$ and the freedom of assembly of migrant workers. ${ }^{48}$

However, these treaties were drafted at the time of the Cold War and should not be read too broadly. At the time, ideological differences between Western and Communist states prevented a reading of universal human rights treaties

\footnotetext{
${ }^{40}$ Art 29(2) of the UDHR provides: 'In the exercise of his rights and freedoms, everyone shall be subject only to such limitations as are determined by law solely for the purpose of securing due recognition and respect for the rights and freedoms of others and of meeting the just requirements of morality, public order and the general welfare in a democratic society'.

${ }^{41}$ ICESCR Art 4.

${ }^{42}$ Ibid, Art 8(a) and (c).

${ }^{43}$ ICCPR Art 14.

${ }^{44}$ Ibid, Art 21

${ }^{45}$ Ibid, Art 22.

${ }^{46}$ CRC Art 15.

${ }^{47}$ ICPRMRW Art 26.

${ }^{48}$ Ibid, Art 40.
} 
with a particular political system in mind. ${ }^{49}$ In this vein, when the ICJ decided the Nicaragua case in 1986, several treaties containing the phrase 'democratic society' were already in force. While the phrase cannot be read as a commitment to a particular political system or electoral method, in the absence of judicial interpretations of its scope, even the meaning of the phrase remains undefined.

This is different in some regional human rights treaties. The ECHR also attaches limitation clauses on certain rights if 'necessary in a democratic society'. Such clauses are found in the context of the right to a fair trial, ${ }^{50}$ the right to respect for private life and family, ${ }^{51}$ the right to freedom of thought, conscience and religion, ${ }^{52}$ the right to freedom of expression, ${ }^{53}$ and the right to freedom of assembly and association. ${ }^{54}$ In this respect, the ECHR does not textually differ from the ICCPR. However, through interpretation of a 'democratic society', the European Court progressively established a much closer and more specific link between human rights and democracy. In Handyside $v$ United Kingdom, the European Court interpreted the phrase 'democratic society' in the context of the freedom of expression:

Freedom of expression constitutes one of the essential foundations of [...] a [democratic] society, one of the basic conditions for its progress and for the development of every man [...] This means, amongst other things, that every 'formality', 'condition', 'restriction' or 'penalty' imposed in this sphere must be proportionate to the legitimate aim pursued. ${ }^{55}$

The relationship between the right to freedom of expression and democracy was reaffirmed in subsequent case law. ${ }^{56}$ In essence, the European Court

\footnotetext{
${ }^{49}$ R Rich, 'Bringing Democracy into International Law' (2001) 12 J Democracy 20, 20-1. See generally also S Marks, 'The European Convention on Human Right and its "Democratic Society”" (1995) 66 BYIL 209.

${ }^{50}$ ECHR Art 6(1).

${ }^{51}$ Ibid, Article 8(2).

${ }^{52}$ Ibid, Article 9(2).

${ }^{53}$ Ibid, Article 10(2).

${ }^{54}$ Ibid, Article 11(2).

${ }^{55}$ Handyside $v$ United Kingdom (1976) 1 EHRR 737, para 49.

${ }^{56}$ See Lingens v Austria (1986) 8 EHRR 407, para 41; Oberschlick v Austria (1991) 19 EHRR 389, para 57; Castells v Spain (1992) 14 EHRR 445, para 42; Jersild v Denmark (1995), 19 EHRR 1, para 31; Goodwin v United Kingdom, (1996) 22 EHRR 123, para 39; Karhuvaara and Iltalehti v Finland (2005) 41 EHRR 51, para 37; Busuioc v Moldova (2005) 42 EHRR 252, para 58; and Steel and Morris v United Kingdom (2005) 41 EHRR 22, para 87.
} 
has established that the limitation clause cannot be triggered arbitrarily, and a legitimate aim must be pursued.

Similarly, the ACHR makes a reference to 'democratic institutions' in the preamble, ${ }^{57}$ while the right to assembly, ${ }^{58}$ freedom of association, ${ }^{59}$ and freedom of movement and residence ${ }^{60}$ invoke the interest of a 'democratic society' as a limitation clause. Article 32 provides for a general limitation clause: 'The rights of each person are limited by the rights of others, by the security of all, and by the just demands of the general welfare, in a democratic society. ${ }^{61}$ Article 28 provides that the ACHR rights need to be interpreted with democracy in mind: 'No provision of [the ACHR] shall be interpreted as [...] precluding other rights or guarantees that are inherent in the human personality or derived from representative democracy as a form of government. ${ }^{32}$

The term 'representative democracy' has been addressed in reports of the Inter-American Commission on Human Rights, where the Commission 'underlined the direct relationship between representative democracy and the guarantee of the observance of human rights. ${ }^{\text {'63 }}$ But phrases such as 'necessary in a democratic society' and 'representative democracy' were not interpreted any further by the Commission. 'Representative democracy' was, however, considered by the Inter-AmericanCourt in Yatama v Nicaragua, and interpreted as follows:

States may establish minimum standards to regulate political participation, provided they are reasonable and in keeping with the principles of representative democracy. These standards should guarantee, among other matters, the holding of periodic free and fair elections based on universal, equal and secret suffrage, as an expression of the will of the voters, reflecting the sovereignty of the people, and bearing in mind, as established in Article 6 of the Inter-American

\footnotetext{
${ }^{57}$ ACHR Preamble, para 1.

${ }^{58}$ Ibid, Art 15.

${ }^{59}$ Ibid, Art 16.

${ }^{60}$ Ibid, Art 22.

${ }^{61}$ Ibid, Art 32(2).

${ }^{62}$ Ibid, para 29(c).

${ }^{63}$ A A Cançado-Trindade, 'The Inter-American Human Rights System at the Dawn of the New Century: Recommendations for Improvements of its Mechanisms of Protection', in D Harris and S Livingstone (eds.), The Inter-American System of Human Rights (1998) 410.
} 
Democratic Charter, that ' $[\mathrm{p}]$ romoting and fostering diverse forms of participation strengthens democracy, ${ }^{64}$

This position reaffirms that implementation of a particular modality of political system is within the domestic jurisdiction of states. However, when interpreting 'democratic society' and 'representative democracy', the Inter-American Court remained confined to electoral procedures. The European Court has arguably interpreted democracy beyond electoral procedures, as the next section demonstrates.

\subsection{Establishing 'imminence' through interpretation}

In Refah Partisi v Turkey, the European Court considered that:

[...] a State cannot be required to wait, before intervening, until a political party has seized power and begun to take concrete steps to implement a policy incompatible with the standards of the Convention and democracy. ${ }^{65}$

However, as articulated in the earlier United Communist Party of Turkey case, such a measure needs to be 'proportionate to the legitimate aim pursued'. 6 According to the Court, the anti-democratic nature of a political party can only be judged from its actions or its programme and not from its name, even where the name implies a particular ideology. For this reason, the Court concluded that the United Communist Party of Turkey posed no automatic threat to the democratic political order, by choosing to call itself 'Communist.' ${ }^{6}$ The Court at this point acknowledged a clear distinction between the United Communist Party of Turkey and the German Communist Party. The latter was dissolved by the Federal Constitutional Court of Germany in 1956 on the basis of its express anti-democratic programme, rather than the word 'Communist' in its name. ${ }^{68}$

\footnotetext{
${ }^{64}$ Yatama $v$ Nicaragua, Judgment of 23 June 2005, para 207 (Inter-American Court of Human Rights).

${ }^{65}$ Refah Partisi and Others $v$ Turkey (2003) 37 EHRR 1, para 102 (Refah Partisi).

${ }^{66}$ United Communist Party of Turkey, above n 17, para 47.

${ }^{67}$ Ibid, para 54.

${ }^{68}$ See Kommunistische Partei Deutschlands-Verbotsurteil, BVerfGE 5, 85, 17 August 1956. The German Communist Party, inter alia, declared as its goals the 'dictatorship of the proletariat', the 'opposition to the democratic order' of the Federal Republic of Germany, and 'propaganda of the Marxist-Leninist teachings'. The Constitutional Court of Germany accepted the application
} 
The European Court adopted the model developed by the German Constitutional Court, which established that dissolution of a democracy-hostile party is a legitimate act where it aims to preserve democratic order, but such an act needs to be subject to rigorous judicial review. As the German Constitutional Court put it: 'The dissolving of a Party is not an independent executive measure but a law-prescribed regular, typical and adequate consequence of finding a violation of the constitutional order. ${ }^{69}$ While the German Court carefully considered the goals and the actions of the German Communist Party, this was not done by the Constitutional Court of Turkey when it dissolved the United Communist Party of Turkey. The latter had expressly democratic goals and was given no time to engage in any anti-democratic activities, given that it was dissolved on the tenth day of its existence. The European Court thus refused the Constitutional Court of Turkey's broad interpretation of the phrase 'necessary in a democratic society' and declared its decision 'disproportional' and 'unnecessary in a democratic society. ${ }^{70}$

The United Communist Party of Turkey case established the interpretative standard requiring that the reasons for dissolving a political party-and thus restrictions on the freedom of assembly-need to be 'convincing and compelling. ${ }^{71}$ The threshold established in this case was confirmed in subsequent case law. ${ }^{72}$ While United Communist Party of Turkey determines when a political party cannot be justifiably banned, the interpretation of the freedom of assembly in Refah Partisi determines the other parameter of this right, namely when a political party can be dissolved. The European Court relied on examination of a 'pressing social need' for such a restriction. ${ }^{73}$ A 'pressing social need' was determined after examining the following questions:

(i) whether the risk to democracy was sufficiently imminent; (ii) whether the acts and speeches of the leaders of the party under consideration [...] could be imputed to the party itself; and (iii)

of the German Government, arguing that (at section 3, para 1): 'The goals of the German Communist Party and the behaviour of its adherents aim at hindering, even abolishing, the liberal democratic fundamental order, and endangering the very existence of the Federal Republic of Germany' (author's translation).

${ }^{69}$ Ibid, section 3, para 2 (author's translation).

${ }^{70}$ United Communist Party of Turkey, above n 17, para 61.

71 Ibid, para 46.

72 See Socialist Party and Others $v$ Turkey (1999) 27 EHRR 51, paras 41-50; Freedom and Democracy Party (ÖZDEP) v Turkey (1998) 26 EHRR 121, paras 37-48.

${ }^{73}$ Refah Partisi, above n 65, para 132. 
whether the acts and speeches imputable to the party constituted a whole, which gave a clear picture of the model of society advocated by the party, and whether this model was compatible with the concept of 'democratic society.' ${ }^{\text {' }}$

In Refah Partisi, the Court observed that the political party in question (the 'Welfare Party' or 'Prosperity Party') was a threat to Turkish secularism, which is a central concept in the modern Turkish state and its liberal-democratic order. ${ }^{75}$ In so doing, the European Court referred to the reasoning of the Turkish Constitutional Court:

Several members of Refah, including some in high office, had made speeches calling for the secular political system to be replaced by a theocratic regime. These persons had also advocated elimination of the opponents of this policy, if necessary by force. Refah, by refusing to open disciplinary proceedings against the members concerned and even, in certain cases, facilitating dissemination of their speeches, had tacitly approved the views expressed. ${ }^{76}$

The Court ultimately concluded:

In making an overall assessment of the points it has just listed above in connection with its examination of the question whether there was a pressing social need for the interference in issue in the present case, the Court finds that the acts and speeches of Refah's members and leaders cited by the Constitutional Court were imputable to the whole of the party, that those acts and speeches revealed Refah's long-term policy of setting up a regime based on sharia within the framework of a plurality of legal systems and that Refah did not

\footnotetext{
${ }^{74}$ A Heringa and F van Hoof, 'Freedom of Association and Assembly' in P van Dijk et al, Theory and Practice of the European Convention on Human Rights (2006) 829. See also Partidul Comunistilor and Ungureanu v Romania (2007) 44 EHRR 17, para 48.

75 'The Court further observes that there was already an Islamic theocratic regime under Ottoman law. When the former theocratic regime was dismantled and the republican regime was being set up, Turkey opted for a form of secularism which confined Islam and other religions to the sphere of private religious practice. Mindful of the importance for survival of the democratic regime of ensuring respect for the principle of secularism in Turkey, the Court considers that the Constitutional Court was justified in holding that Refah's policy of establishing sharia was incompatible with democracy': Refah Partisi, above n 65, para 125.

${ }^{76}$ Ibid, para 12.
} 
exclude recourse to force in order to implement its policy and keep the system it envisaged in place. In view of the fact that these plans were incompatible with the concept of a 'democratic society' and that the real opportunities Refah had to put them into practice made the danger to democracy more tangible and more immediate, the penalty imposed on the applicants by the Constitutional Court, even in the context of the restricted margin of appreciation left to Contracting States, may reasonably be considered to have met a 'pressing social need. ${ }^{77}$

Refah was dissolved on the basis of a pressing social need and imminence, as it was a threat to democratic political order. It is of particular importance that imminence was established on the basis of Refah's popularity, influence and realistic prospects of becoming the strongest political party in Turkey. This is how the Court reasoned:

Refah was founded in 1983, took part in a number of general and local election campaigns and obtained approximately $22 \%$ of the votes in the 1995 general election, which gave it 158 seats in the Grand National Assembly (out of a total of 450 at the material time). After sharing power in a coalition government, Refah obtained about 35\% of the votes in the local elections of November 1996. According to an opinion poll carried out in January 1997, if a general election had been held at that time Refah would have received 38\% of the votes. According to the forecasts of the same opinion poll, Refah could have obtained $67 \%$ of the votes in the general election likely to be held about four years' later [...] Notwithstanding the uncertain nature of some opinion polls, those figures bear witness to a considerable rise in Refah's influence as a political party and its chances of coming to power alone. ${ }^{78}$

In the Court's interpretation, a pressing social need existed because Refah was likely to win the elections, and it decided to uphold the exclusion of the likely winner from the electoral process. Indeed, the party was dissolved precisely

\footnotetext{
${ }_{77}$ Ibid, para 132.

${ }^{78}$ Ibid, para 107. The Court's reliance on opinion polls was criticised by Judge Kovler in his concurring opinion (para 49): 'I find the use of figures derived from opinion polls [...] which would be natural in a political analysis, rather strange in a legal text which constitutes res judicata'.
} 
because of its influence and size. ${ }^{79}$ The Court thereby extended its understanding of democracy beyond the electoral process and the will of the people. It upheld the idea that people should not even be given a chance to vote for an anti-democratic political party.

A broader understanding of democracy also follows from other cases where national legislation limited the 'democratic rights' of certain individuals. In Rekvenyi v Hungary, the Court addressed the question of whether the Hungarian prohibition on members of police, military, and security forces joining political parties was a violation of Article 11 of the ECHR. The Court considered the Hungarian experience with Communism where police, military and security forces were politicised and subordinated to the Party. ${ }^{80}$ These circumstances spoke in favour of the ban, as specifically acknowledged by the Court:

Bearing in mind the role of the police in society, the Court has recognised that it is a legitimate aim in any democratic society to have a politically neutral police force [...] In view of the particular history of some Contracting States, the national authorities of these States may, so as to ensure the consolidation and maintenance of democracy, consider it necessary to have constitutional safeguards to achieve this aim by restricting the freedom of police officers to engage in political activities and, in particular, political debate. ${ }^{81}$

In other words, a limitation of the right of members of police, military, and security forces to join political parties would have been permissible in certain circumstances and such a limitation could be beneficial for the 'consolidation and maintenance of democracy'. This is a further step further from an electoral-centric definition of democracy. By references to democratic consolidation, the Court clearly adopted a more substantive definition of democracy than one based solely on electoral procedures. In Rekvenyi, the prohibition was declared to be a violation of Article 11, as the level of democratic consolidation in post-Communist Hungary was regarded as sufficient to accommodate the possibility that members of the police force might join political parties.

\footnotetext{
${ }^{79}$ Cf B Roth, 'Democratic Intolerance: Observations on Fox and Notle' in G Fox and B Roth, above $\mathrm{n} 3,442$, arguing that it is rather odd to send a message that democracy gives people an option to choose any kind of government, except the one that most of them currently think they want to have. The European Court arguably adopted such reasoning, but used it in a pre-emptive way to prevent Refah Partisi from winning the forthcoming election.

${ }^{80}$ Rekvenyi v Hungary (2000) 30 EHRR 519, para 47.

${ }^{81}$ Ibid, para 42.
} 
Although the factual circumstances were different, a similar question was raised in Ždanoka $v$ Latvia. ${ }^{82}$ The Court decided that the national limitation on the right to stand for an election to a person who was actively involved in the activities of the Communist Party of Latvia $(C P L)$ was disproportionate and not necessary in a democratic society. ${ }^{83}$ By holding that 'neither a parliament nor an individual member of parliament may, by definition, be "politically neutral", 84 the Court drew a distinction between Ždanoka and Rekvenyi. However, the underlying question was similar: under what circumstances can an individual's 'democratic rights' be limited in the interests of a democratic society?

The Government of Latvia submitted that former members of the CPL were a threat to Latvian democracy, as the CPL had sponsored subversive actions against the elected Latvian government, following the first democratic elections in $1990 .{ }^{85}$ The Government thus claimed that the limitation of the right to stand for an election to former members of the CPL was 'necessary in a democratic society', as democracy needs to be able to defend itself. The Court rejected this view on the basis that:

[...] the applicant's disqualification from standing for election to Parliament and local councils on account of her active participation in the CPL, maintained more than a decade after the events held against that party, is disproportionate to the aim pursued and, consequently, not necessary in a democratic society. ${ }^{86}$

The Court thereby expressly upheld the view of the dissenting opinion of three out of seven judges of the Constitutional Court of Latvia, which held that the Latvian democratic system had become sufficiently strong for it no longer to fear the presence within its legislative body of persons who had campaigned against the system ten years previously. ${ }^{87}$ The decision of the European Court was based on the premise that the state of Latvian democracy ten years after the subversive

\footnotetext{
${ }^{82}$ Ždanoka v Latvia (2007) 45 EHRR 17.

${ }^{83} \mathrm{Ibid}$, para 110. This decision is interesting in light of the lustration laws adopted in some post-Communist states. See V Pettai, 'Estonia: Positive and Negative Institutional Engineering', in A Pravda and J Zielonka (eds), Democratic Consolidation in Eastern Europe Volume 1: Institutional Engineering (2001) 126-7.

${ }^{84}$ Ždanoka v. Latvia, above n 82, para 85.

${ }^{85}$ Ibid, para 66.

${ }^{86}$ Ibid, para. 110.

${ }^{87}$ Constitutional Court of Latvia, Judgment of 30 August 2000, cited in Ždanoka v Latvia, above n 82 , para 49.
} 
events was at a level where such restrictions were no longer necessary and could no longer be justified. ${ }^{88}$ The Court again looked beyond formal democratic procedures and based its decision upon the level of democratic consolidation in Latvia. It clearly follows from the decision that the outcome could have been different in the circumstances of a more vulnerable democracy.

The Court thus not only interprets the ECHR as an instrument that guarantees multiparty elections. It has gone further and made defending democracy one of its functions, developed by interpretation of the rights in the ECHR. In so doing, the Court even resorts to opinion polls and electoral predictions to assess the level of democratic consolidation.

\section{Conclusion}

Textually, no human rights treaty mentions multiparty elections and/or binds contracting parties to a particular political system or electoral method. However, international and regional judicial bodies can interpret human rights treaties with a particular political system in mind. In principle, the ICCPR remains politically neutral. The only clear judicial interpretation on the matter remains the 1986 Nicaragua case, where the ICJ could not 'find an instrument with legal force [...] whereby Nicaragua ha[d] committed itself in respect of the principle or methods of holding elections. ${ }^{\prime 89}$ In the absence of a centralised judicial body with compulsory jurisdiction at the international level, there is a lack of further judicial practice providing for interpretations of the ICCPR other than that offered in Nicaragua. It is worth noting that, a decade later, the HRC avoided a reference to multiparty elections in its comment on the right to political participation under the ICCPR.

The relationship between human rights treaties and multiparty democracy is more elaborate in regional human rights systems in which treaty provisions are interpreted by specialised human rights courts. All three regional human rights courts reject the idea that elections can be free and fair in a single party setting. The European Court, in particular, has developed very robust case law to this effect. Besides providing unambiguous authority that multiparty democracy is a part of the European public order, the Court has also considered the requisite

\footnotetext{
${ }^{88}$ For further discussion on Latvian democracy, see, A Sprudzs, 'Rebuilding Democracy in Latvia: Overcoming a Dual Legacy', in A Pravda and J Zielonka (eds), Democratic Consolidation in Eastern Europe Volume 1: Institutional Engineering (2001) 139-64.

${ }^{89}$ Nicaragua, above n 8, para 261.
} 
level of democratic consolidation and upheld limitations on human rights for the protection of a democratic political system. At the same time, all human rights courts have allowed for a wide margin of appreciation and do not impose on parties to the respective treaties a specific institutional arrangement. In other words, it is understood that human rights treaties require multiparty elections and also that democracy is not only understood narrowly as an electoral process. But many different national political systems can fall within these parameters.

Besides the question of whether human rights treaties require multiparty elections, it is also controversial whether a system which allows political participation only through party politics can be compatible with human rights treaties. In $A P v$ Russia, the HRC missed an opportunity to address the question of whether individuals can be forced to associate in political parties in order to run at elections. Article 25 of the ICCPR does not even mention political parties, yet it seems to be increasingly accepted that parties are at the heart of an institutional arrangement for exercising this right. Individuals can indeed be forced to act through political parties if they wish to run at elections. Is this still a democracy, understood as the rule of the people, or is it rather the rule of political parties? The issue is also very pressing at the regional level.

In Tanganyika Law Society, the African Court established that political participation is not reserved exclusively for candidates backed by political parties. However, because the Tanzanian constitution specifically required membership in political parties, it is possible to see this case as limited by its factual circumstances. The Inter-American Court has accepted that people may be forced to seek party support in order to run at elections. As long as they are not forced to join a party, the ACHR is not breached. In the otherwise inadmissible case, AP v Russia, even the HRC hinted that the solution would be in taking this 'middle option'. However, making a distinction between being forced to join a party and being forced 'only' to seek support of a party does not really solve the problem. As AP v Russia demonstrates, seeking party support also comes with pressure to associate with others with a particular party programme or ideology. Judicial bodies have not adequately scrutinised the features of different multiparty electoral systems. Some systems indeed require party lists and in such circumstances it may be justifiable to 'force' candidates to associate with political parties in this way. But other electoral systems can accommodate independent candidates and the requirement to seek support by political parties does not seem to be necessary for the electoral process.

Judicial bodies, especially regional human rights courts, have interpreted human rights treaties as requiring multiparty elections. But political parties now 
seem to have a chequered role which can also lead to violations of 'democratic rights'. As the African Court put it, individuals should not be forced to associate with others and the Tanganyika Law Society case should not be disregarded in future judicial interpretations of human rights treaties simply because the Tanzanian constitution specifically required membership of a political party. 